\title{
The importance of dung beetles and arthropod communities on degradation of cattle dung pats in eastern South Dakota
}

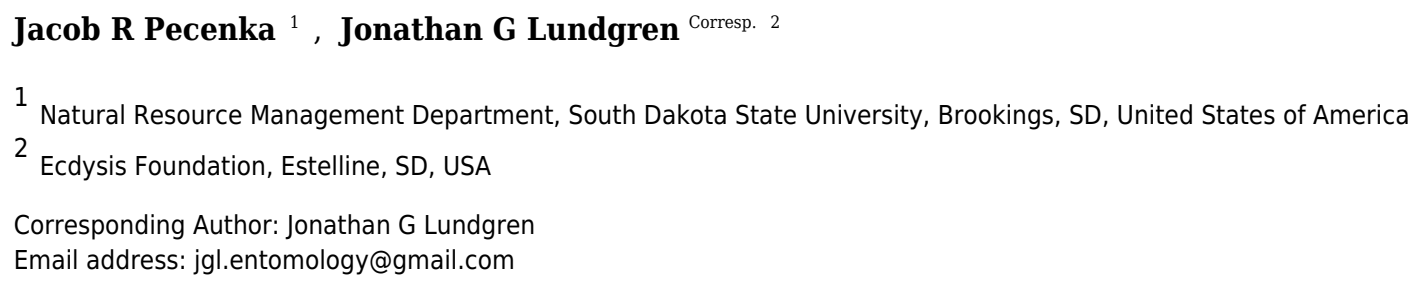

Background. Dung accumulation in rangelands can suppress plant growth, foul pastures, and increase pest pressure. Here, we describe the arthropod community of dung in eastern South Dakota, and quantify their contributions to dung degradation using an exclusion cage design. Methods. Various arthropod community and degradation characteristics were measured in caged and uncaged dung pats over time in early and late summer. Results. A total of 86,969 specimens were collected across 109 morphospecies (13 orders) of arthropods, and cages effectively reduced arthropod abundance, species richness, and diversity. Uncaged dung pats degraded significantly faster than the caged pats, with the largest difference occurring within $2 \mathrm{~d}$ of pat deposition. Dung organic matter was degraded more slowly (by 33-38 d) in the caged pats than pats where insects had free access to the pats. Although dung beetles only represented $1.5-3 \%$ of total arthropod abundance, they were significantly correlated to more abundant and complex total arthropod communities. Discussion. A diverse community contributes to dung degradation in rangelands, and their early colonization is key to maximizing this ecosystem service. 
1 A revised submission for: PeerJ

2

3 The importance of dung beetles and arthropod communities on degradation of cattle dung

4 pats in eastern South Dakota

5

6

7 Jacob R. Pecenka ${ }^{1,2}$ and Jonathan G. Lundgren*

$8{ }^{1}$ Department of Natural Resource Management, South Dakota State University, Brookings, SD,

9 USA, 57007

$10 \quad{ }^{2}$ Ecdysis Foundation, Estelline, SD, USA, 57234

11

12

13

14

$15 *$ Address correspondence to:

16 Dr. Jonathan Lundgren

17 Ecdysis Foundation

$1846958188^{\text {th }}$ Street

19 Estelline, SD, USA, 57234

20 E-mail: jgl.entomology@gmail.com

21 Ph: 605-695-9878 


\section{Abstract}

23 Background. Dung accumulation in rangelands can suppress plant growth, foul pastures, and

24 increase pest pressure. Here, we describe the arthropod community of dung in eastern South

25 Dakota, and quantify their contributions to dung degradation using an exclusion cage design.

26 Methods. Various arthropod community and degradation characteristics were measured in caged

27 and uncaged dung pats over time in early and late summer.

28 Results. A total of 86,969 specimens were collected across 109 morphospecies (13 orders) of

29 arthropods, and cages effectively reduced arthropod abundance, species richness, and diversity.

30 Uncaged dung pats degraded significantly faster than the caged pats, with the largest difference

31 occurring within $2 \mathrm{~d}$ of pat deposition. Dung organic matter was degraded more slowly (by 33-38

32 d) in the caged pats than pats where insects had free access to the pats. Although dung beetles

33 only represented $1.5-3 \%$ of total arthropod abundance, they were significantly correlated to more

34 abundant and complex total arthropod communities.

35 Discussion. A diverse community contributes to dung degradation in rangelands, and their early 36 colonization is key to maximizing this ecosystem service. 


\section{Introduction}

When cattle excrete dung onto the soil surface, the failure of the pats to break down can challenge the productivity of grazing on rangelands (Fincher 1981). When cattle consume forage, any nutrients not digested are returned to the system in the form of dung and urine (Haynes \& Williams 1993; Wu \& Sun 2010). The undigested plant material that comprises dung is deposited on the soil surface, smothering plant growth in that area (Holter 2016; MacLusky 1960). Pasture fouling through continuous dung deposition that fails to degrade quickly can represent a substantial problem to ranchers if left unmanaged. When a dung pat is deposited on a pasture, all of the available forage underneath and up to a $5 \mathrm{~m}$ radius around the pat is unused by grazing cattle until the pat is incorporated into the soil (Weeda 1967). Dung loses 22\% (but up to $80 \%$ ) of its nitrogen $(\mathrm{N})$ to volatilization within $60 \mathrm{~d}$ of deposition (Nichols et al. 2008; Weeda 1967). Other important nutrients such as phosphorus (P) and potassium (K) are present in dung pats in much smaller quantities and can be lost to leaching and runoff when left on the soil surface (Gillard 1967; Nichols et al. 2008; Petersen et al. 1956). Volatilization and reductions of these elements decreases the nutrient availability to the plant community, resulting in lower quantity and quality of forage for future cattle grazing (Aarons et al. 2009; Bang et al. 2005).

A variety of factors affect how quickly dung is incorporated into the soil. Reports of dung degradation rates vary from 50-65 d over the season (Holter 1979), 57-78 d in late spring to 88$111 \mathrm{~d}$ in late summer (Lee \& Wall 2006), and up to 3 y in cattle grazing systems with high insecticide use (Anderson et al. 1984; Strong 1992). This variability is due to factors that include weather (Holter 1979), seasonality (Lee \& Wall 2006), insecticide use (Suarez et al. 2003), and the nutritional quality of the dung itself (Cook et al. 1996). Degradation of dung pats is facilitated by arthropods that accelerate the incorporation of the dung pat organic matter into the 
62 soil, and improve soil's aeration and water holding capacity (Macqueen \& Beirne 1975). Dung

63 often supports dozens or even hundreds of arthropod species (Blume 1985; Merritt \& Anderson

64 1977; Valiela 1969).

65 Arthropods that colonize dung pats can be categorized into different functional guilds that 66 each contribute to the eventual incorporation of the dung into the soil. One of the first studies

67 that considered dung community function was Mohr (1943), which prompted other studies that 68 documented arthropod succession in a dung pat and their varying niches within the micro-habitat 69 (Cervenka \& Moon 1991; Koskela \& Hanski 1977; Sanders \& Dobson 1966). These studies are 70 accompanied by more recent explorations of the importance of dung beetles (Scarabaeidae) and

71 the multiple ecosystem services that they provide (Beynon et al. 2012; Manning et al. 2016;

72 Nichols et al. 2008). One of these ecosystem services is dung beetles' ability to increase the 73 productivity of rangeland ecosystems (Bang et al. 2005; Penttila et al. 2013). Increased rangeland

74 productivity is achieved by bioturbation and burial of dung that results in capturing ephemeral 75 nutrients for surrounding forage plants up to $12.7 \mathrm{~cm}$ away from the dung pat (Bornemissza 76 1970; Macqueen \& Beirne 1975; Yamada et al. 2007). A second important ecosystem service is 77 the suppression of dung inhabiting pests to grazing cattle (Fincher 1981). By removing 78 nutritional resources and habitat, dung beetles reduce pest maggot abundance (Doube 1990;

79 Nichols et al. 2008). Suppressing these pests is accelerated by the colonization by natural 80 enemies such as predatory staphylinid or hister beetles and parasitoid wasps to the dung pat

81 (Cervenka \& Moon 1991). These ecosystem services provided by dung beetles (as well as other 82 members of the dung arthropod community) have an economic value to the ranching operation 83 (Beynon et al. 2015), but most of the numbers used to generate these values are at least 37 years 84 old (Beynon et al. 2012; Fincher 1981; Losey \& Vaughan 2006). 
The goal of our study was to document the dung insect community in eastern South Dakota, and determine dung degradation rates over time in the presence and absence of this community.

87 Cages like those employed here help to isolate the contribution of the majority of the arthropod 88 community to dung pat degradation (Lee \& Wall 2006; Tixier et al. 2015). Here, we pair cages with a comprehensive description of invertebrate communities within the dung both early and late in the summer to understand how elements of this community affect degradation over the season. There are 9.12 million ha of rangeland in South Dakota (USDA-NASS), and this region represents an important transition zone between the mid and tall-grass prairie biomes. Dunginhabiting Coleoptera from South Dakota were described nearly 50 years ago (Kessler \& Balsbaugh 1972; McDaniel et al. 1971), but these studies did not correlate these arthropods to dung pat degradation and land use patterns have changed dramatically toward annual cropland over this period of time (Johnston 2014; Wright \& Wimberly 2012). Identifying the impact of the

97 dung arthropod community on degradation will provide ranchers a greater understanding of the benefits to conserving this poorly understood community. We hypothesize that caging pats will reduce insect colonization of the dung and impede pat degradation rates.

\section{Materials and Methods}

Study site. This study was conducted on a ranch in eastern South Dakota, U.S., at 44.758,

-96.538 in the summer of 2016 . The study site was at an altitude of $559 \mathrm{~m}$ in an area with an average annual rainfall of $684 \mathrm{~mm}$ and an average summer temperature of $19.8^{\circ} \mathrm{C}$. The 130 ha pasture was composed of mixed grasses; consisting mostly of Schizachyrium scoparium (little bluestem), Andropogon gerardii (big bluestem) and Spartina pectinata (prairie cordgrass) with 
108 to and during the experiment had a 130-steer herd made up of Angus, Belted Galloway, and Irish

109 Black breeds, that was moved among small 0.41-1.21 ha paddocks approximately every $24 \mathrm{~h}$.

110 Cattle were excluded from the experimental site during the observation periods. No insecticide or

111 nematicide treatments had been used on cattle on this ranching operation in more than $10 \mathrm{y}$.

112 Dung degradation measurements. Dung ( $<2 \mathrm{~h}$ old; $90 \mathrm{~kg}$ collected twice) was collected

113 from the pasture on 04/06/2016 and 05/06/2016 before 10:00. Fresh dung pats were

114 homogenized and stored in bags at $-25^{\circ} \mathrm{C}$ for $72 \mathrm{~h}$ to ensure all arthropods had been killed. Dung

115 was removed from the freezer, completely thawed, and homogenized prior to use in the

116 experiment. Aliquots of the dung $(1000 \pm 10 \mathrm{~g})$ were weighed, individually bagged, and stored

117 for $24 \mathrm{~h}$ before placing them in the field. Each bag of weighed dung became a "sentinel pat" to

118 represent a dung pat deposited by grazing cattle. Observation sites $(n=84)$ were placed in the

119 pasture so sites were at least $5 \mathrm{~m}$ apart. At each site, a sentinel pat was placed on top of mesh

120 with $2.5 \mathrm{~cm}$ square holes to allow for ease of pat removal. Each site was randomly assigned to

121 one of three treatments. In the first treatment (inclusion; $n=36$ ), dung pats were left completely

122 exposed with no covering. In the second treatment (exclusion; $n=36$ ), the pats were surrounded

123 by a PVC cylinder ( $25 \mathrm{~cm}$ diam., $25 \mathrm{~cm}$ tall), buried at least $12 \mathrm{~cm}$ into the ground to reduce

124 ground colonization of the pat. The tops of these cylinders were covered in fine mesh screen $(<1$

125 mm opening) and secured with plastic tie. The final control treatment (sham cage; $n=12$ ) used

126 the same cylinder design as the exclusion treatment, but with three $10 \times 10 \mathrm{~cm}$ holes cut on the

127 sides to allow arthropods to travel into the cylinder. A wire top was used to cover these sham

128 cylinders that had $3 \mathrm{~cm}$ openings. This third treatment was added to test whether the exclusion

129 cage had direct effects on dung degradation rates. 
To determine degradation rates, pats from the three treatments were weighed over time.

131 The entire experiment was repeated twice over the season, once beginning on 10-June and once

132 on 28-July. Randomly selected pats (Inclusion [6 pats], Exclusion cage [6], and Sham cage [2]

133 on each time point) were removed $2,4,7,14,28$, and $42 \mathrm{~d}$ after the sentinel pats were placed. At

134 the time of removal, the pat was collected in a plastic bag, sealed and taken to the laboratory.

135 Each pat was weighed while still fresh and after drying to constant weight (over 7-10 d). A 10-

136 gram sample of this dried pat was ground to a fine powder and baked at $500^{\circ} \mathrm{C}$ for $1 \mathrm{~h}$; the

137 remaining sample was then re-weighed to determine ash/mineral content of the sample. From

138 this value the ash-free organic matter content (AFOM) of the pat was calculated.

140 funnel system for $7 \mathrm{~d}$ to extract arthropods living in the dung pat. The top of the extraction

141 funnel sealed with the top board of this extraction system, eliminating the ability of winged

142 arthropods to escape. The arthropods were identified under a microscope and then weighed to

143 calculate arthropod biomass. To help characterize this diverse arthropod community, each

144 specimen was identified to the lowest taxonomic level possible. Specimens were identified to at

145 least the family level using Triplehorn and Johnson (2005); and scarabid beetles were identified

146 to species by Ratcliffe and Paulsen (2008). Within these families, each specimen was assigned to

147 a morphospecies and functional guild depending on their feeding ecology. The non-pest

148 coprophagous community was divided into macro-coprophages ( $>1 \mathrm{~mm}$ long; Scarabaeidae,

149 Hydrophilidae), and micro-coprophages (< $1 \mathrm{~mm}$ long; Acarina, Collembola, Ptiliidae).

150 Data analysis. All statistics were conducted using Systat 13 (SYSTAT Software, Inc;

151 Point Richmond, CA). Two-way ANOVAs were used to investigate how dung pat age and cages

152 affected dung pat and arthropod characteristics including pat wet weight, dry weight, moisture 
153 content, organic matter content, and arthropod biomass, abundance, species richness (number of

154 morphospecies found), species diversity (Shannon H), and abundance of family Scarabaeidae. To

155 avoid possible pseudoreplication and sampling bias, separate analyses were conducted on data

156 collected early and late in the season. ANOVAs were used to compare the abundances of

157 coprophages, predators, parasitoids, herbivores, and maggots collected per pat early and late in

158 the season. Linear regressions were generated to compare the number of dung beetles to dung pat 159 organic matter, total arthropod biomass, arthropod abundance, species richness, species diversity

160 and micro-coprophage abundance (pooled across pat ages and early/late season observations).

161 Many cross comparisons of different community characteristics and response variables can lead

162 to false positives, or type I errors, in our analyses. Prior to running any statistical tests, we

163 always investigate the patterns in the data, looking for biologically meaningful trends. This helps

164 to reduce the likelihood of type I errors and increase the relevance of our results.

Results

Dung arthropod community. A total of 109 morphospecies (86,969 arthropod specimens) were collected from dung pats, representing 13 orders (Acarina, Araneae, Coleoptera, Pseudoscorpiones, and Thysanoptera). There were $517.68 \pm 30.98$ (mean \pm SEM) larval and

171 adult specimens collected (228.02 $\pm 46.05 \mathrm{mg}$ of arthropods), represented by $13.32 \pm 0.49$

172 morphospecies, per dung pat. Larval communities included only three orders; Diptera (6 173 morphospecies), Coleoptera (17 morphospecies) and Lepidoptera (1 morphospecies). Orders

174 with the most abundant specimens were Acarina $(n=35,534)$, Coleoptera (adult $n=22,689$;

175 larvae $n=6,057)$, Collembola $(n=9,114)$, Diptera (adult $n=609$; larvae $n=8,870$ ), Lepidoptera 
176 (adult $n=8$; larvae $n=2,034)$, and Hymenoptera $(n=1,141)$. Four families of Coleoptera were

177 well represented (they comprised $26 \%$ of all specimens collected): Staphylinidae $(\mathrm{n}=8,140)$,

178 Ptiliidae $(n=9,247)$, Hydrophilidae $(n=3,576)$, Scarabaeidae $(n=1,624)$ were represented by

179 14, 1, 12, and 13 morphospecies from these families; respectively. Trophically, these specimens

180 were categorized as coprophagous (37 morphospecies; 60,564 specimens), predators (38

181 morphospecies; 15,047 specimens), herbivores (18 morphospecies; 2,037 specimens;) or

182 parasitoids (10 morphospecies; 539 specimens). The remaining specimens are regarded as

183 coprophagous maggots (6 morphospecies; 8870 specimens), consisting of Diptera larvae.

184 Arthropods were collected early and late in the summer. Arthropod abundances in the

185 early season were $485.63 \pm 42.18$ (40,765 total) specimens from $12.91 \pm 0.71$ morphospecies per

186 pat; $549.73 \pm 45.36$ (46,269 total) arthropods representing $13.73 \pm 0.67$ morphospecies per pat

187 were collected later in the summer. Arthropod biomass per pat was $357.93 \pm 40.98 \mathrm{mg}$ in the

188 early season and $152.72 \pm 72.40 \mathrm{mg}$ in the late season. Functional group populations changed

189 between the two sampling periods. Coprophage abundance significantly $(\mathrm{F}=5.08$;

$190 \mathrm{df}=1,166 ; \mathrm{P}=0.026)$ increased $26 \%(25,837$ to 34,639$)$, predator abundance significantly

$191 \quad(\mathrm{~F}=9.11 ; \mathrm{df}=1,166 ; \mathrm{P}=0.003)$ increased $40 \%(5,661$ to 9,386$)$, parasitoid abundance

192 significantly $(\mathrm{F}=24.36 ; \mathrm{df}=1,166 ; \mathrm{P}<0.001)$ decreased by $78 \%$ (442 to 97 ), herbivore

193 abundance significantly $(\mathrm{F}=7.89 ; \mathrm{df}=1,166 ; \mathrm{P}=0.012)$ decreased by $53 \%(1,389$ to 648$)$, and

194 maggots significantly $(\mathrm{F}=12.25 ; \mathrm{df}=1,166 ; \mathrm{P}=0.001)$ decreased by $79 \%$ (7371 to 1499$)$ from

195 early to late summer. Dung beetles represented $3 \%$ and $1.5 \%$ of total arthropod abundance in

196 early and late season, respectively.

197 Sham cage effect. The sham cages had similar arthropod communities and dung

198 characteristics with the no cage treatment in 16 of the 18 ANOVAs of different dung arthropod 
199 community groups and dung degradation metrics. Only early season arthropod abundance and 200 late season dung pat wet weight were significantly different between cage treatments, but these

201 trends were not consistent in both early and late seasons. The general lack of differences between

202 the sham cage and no cage treatments indicates that the cage had little direct effect on arthropod 203 communities and dung characteristics, and justifies our focus on cage/no cage comparisons for 204 the remainder of this section.

Treatment and time effect on dung community. Dung pats in the pasture had different

206

207

208

209

210

211

212

213

214

215

216

217

218

219

220

221

arthropod communities when pats were caged and as the dung pat aged. Cages and time had a significant effect on arthropod biomass in the early and late seasons (Figure 1). Arthropod biomass inside the cages was $10 \%$ of the biomass found in the uncaged pats early in the season and caged pats had $13 \%$ of the biomass of the uncaged later in the summer. The biomass and abundances (Figure 2) of arthropods were significantly greater on younger pats $(2,4$ and $7 \mathrm{~d}$ old) versus older pats $(14,28,42 \mathrm{~d}$ old) both early and late in the season. Specifically, the biomasses declined by 72 and $83 \%$ between the $7^{\text {th }}$ and $14^{\text {th }}$ days in early and late season, respectively.

After $14 \mathrm{~d}$, arthropod biomass did not significantly change through $42 \mathrm{~d}$. Caged dung pats only averaged 52\% and 57\% of the arthropod specimens that were found in the inclusion dung pats in early and late seasons, respectively.

Cages did not completely exclude the insect community, but it did reduce the arthropod species richness and diversity. The richness of arthropod species found in the dung pats was significantly affected by cages and time in the early season (exclusion: $F=102.86$; $\mathrm{df}=1,60 ; \mathrm{P}<0.001 ;$ time: $\mathrm{F}=5.08 ; \mathrm{df}=5,60 ; \mathrm{P}<0.001 ;$ interaction: $\mathrm{F}=6.71$; $\mathrm{df}=5,60 ; \mathrm{P}<0.001)$ and in the late season (exclusion: $\mathrm{F}=66.49 ; \mathrm{df}=1,60 ; \mathrm{P}<0.001$; time: $\mathrm{F}=26.44 ; \mathrm{df}=5,60 ; \mathrm{P}<0.001$; interaction: $\mathrm{F}=6.70 ; \mathrm{df}=5,60 ; \mathrm{P}<0.001)$. The mean number of 
222 species in the caged dung pats were $46 \%$ and $62 \%$ of the number in the uncaged pats for the

223 early and late season, respectively. Exclusion and time had a significant effect on arthropod

224 diversity (Shannon $\mathrm{H}$ ) in the early season (exclusion: $\mathrm{F}=34.24$; $\mathrm{df}=1,60 ; \mathrm{P}<0.001$; time:

$225 \mathrm{~F}=10.71 ; \mathrm{df}=5,60 ; \mathrm{P}<0.001 ;$ interaction: $\mathrm{F}=5.03 ; \mathrm{df}=5,60 ; \mathrm{P}=0.001)$ but only time had a

226 significant effect in the late (exclusion: $\mathrm{F}=0.40 ; \mathrm{df}=1,60 ; \mathrm{P}=0.528$; time: $\mathrm{F}=50.19$;

$227 \mathrm{df}=5,60 ; \mathrm{P}<0.001$; interaction: $\mathrm{F}=5.53 ; \mathrm{df}=5,60 ; \mathrm{P}<0.001)$ season. There were significantly

228 more maggots $(\mathrm{F}=47.37 ; \mathrm{df}=2,66 ; \mathrm{P}<0.001)$ in the exclusion than the inclusion pats. Dung

229 beetle abundance was significantly reduced by the arthropod exclusion. In the early season,

230 cages and time had a significant effect on dung beetle abundance (exclusion: $\mathrm{F}=111.55$;

$231 \mathrm{df}=1,60 ; \mathrm{P}<0.001 ;$ time: $\mathrm{F}=17.30 ; \mathrm{df}=5,60 ; \mathrm{P}<0.001 ;$ interaction: $\mathrm{F}=17.95$

$232 \mathrm{df}=5,60 ; \mathrm{P}<0.001)$. Likewise, in the late season cages and time had a significant effect on dung

233 beetle abundance (exclusion: $\mathrm{F}=105.01$; $\mathrm{df}=1,60 ; \mathrm{P}<0.001$; time: $\mathrm{F}=23.85$;

$234 \mathrm{df}=5,60 ; \mathrm{P}<0.001 ;$ interaction: $\mathrm{F}=23.85 ; \mathrm{df}=5,60 ; \mathrm{P}<0.001)$.

235 The effects of arthropod reduction and time on dung degradation. Cages and time had

236 significant effects on dung pat wet weight in both the early and late season (Table 1). Dung from

237 which many insects were excluded had an average of 26.10 and $21.93 \%$ lower wet weights and

238 dry weights (in the early and late seasons) (Table 1) than when arthropods were allowed access

239 to the pats. Pats experienced a $28.3 \pm 1.94 \%$ wet weight loss during the first $2 \mathrm{~d}$ and $79.70 \pm$

$2401.28 \%$ weight loss by day 42 (Table 1). Moisture of dung pats was significantly correlated with

241 arthropod abundance in early $\left(\mathrm{F}_{1,70}=23.59, P<0.001\right)$ and late $\left(\mathrm{F}_{1,70}=9.99, P=0.002\right)$

242 seasons. After drying, the uncaged dung pats contained $25.45 \%$ and $25.10 \%$ less weight than the

243 caged dung pats. 

weight were significantly affected by exclusion cages and time in the early and late seasons

246 (Table 1). Throughout the season the uncaged dung pats had significantly less AFOM than the 247 caged pats. Initially, $90.26 \%$ of dried dung pats were AFOM by weight, and by the 42 nd day it 248 decreased to $69-80 \%$ for uncaged pats and $80-86 \%$ for caged pats. Early season uncaged dung 249 pats averaged 6.8\% less AFOM than caged pats, and late season pats followed a similar trend 250 with $3.14 \%$ less AFOM in the uncaged compared to the caged pats. Early and late season AFOM weight was also significantly affected by exclusion cages and time (Table 1), and the loss of AFOM weight was different between treatments (Figure 3). Early season dung pats with arthropods are estimated to completely degrade before $71 \mathrm{~d}$ and this increases to $104 \mathrm{~d}$ when arthropods are excluded from the pats with cages. Late season dung pats achieve complete breakdown at a faster rate with estimates of $61 \mathrm{~d}$ and $100 \mathrm{~d}$ in uncaged and caged pats respectively. arthropod community recovered, dung beetle abundance, diversity, and richness were always 259 positively correlated with arthropod community characteristics (Table 2). The abundance of dung 260 beetles was significantly and positively correlated with total arthropod biomass, arthropod 261 abundance, total species richness, and abundance of the micro-coprophage community in both 262 the early and late seasons. Dung beetle species richness and diversity was correlated to an 263 increase in abundance of the entire dung arthropod community in both early and late seasons 264 (Table 2) (Figure 4).

\section{Discussion}



Dung pat wet weight, dry weight, moisture percentage, and AFOM all decreased over time during the 42-d observation period (Table 1, Figure 3). The degradation characteristics also show that uncaged pats degraded faster than the caged ones. Ash-free organic matter (AFOM) has

271 been proposed as the most accurate measure of dung pat degradation (Holter 1979). When

272 arthropods were allowed to colonize dung pats, AFOM was reduced substantially within the first $2732 \mathrm{~d}$ (Figure 3). This quicker degradation may be explained by early colonization of the pat by 274 relatively large arthropods. Dung beetles are some of the largest dung arthropods, and the 275 amount of dung they consume and remove from the pat for oviposition is disproportionate 276 compared to their abundance in the dung pats (McDaniel et al 1971). After this first $2 \mathrm{~d}$, the pats 277 degraded at similar rates in both the caged and uncaged pats. When insects were allowed access 278 to the pats, the pats had $32 \%$ of the original AFOM after $42 \mathrm{~d}$; caged pats had $55 \%$ of the AFOM 279 at the end of the observation period. Extrapolations of the data show that insects shorten the lives 280 of pats (i.e., complete AFOM removal) by an estimated $33 \mathrm{~d}$ in the early season, and by $38 \mathrm{~d}$ 281 later in the season. These observations are comparable to dung degradation estimates made in 282 similar studies (Lee \& Wall 2006; Tixier et al. 2015). Often these examples only exclude 283 arthropods for short periods of time or focus on the collection of a single arthropod group, 284 limiting the scale and scope of the observations made. Results show that early dung pat 285 degradation sets the tone for the remainder of the dung pat's time on the soil surface (i.e., the 286 slopes of the regressions presented in Figure 3). This suggests that even a short period of 287 exclusion could have implications for the degradation of a dung pat. Disruptions to early 288 arthropod colonization can have long-term implications to the efficient recycling of dung pats. 
With few exceptions, the cages effectively reduced both the diversity and abundance of

290

291

292

293

294

295

296

297

298

299

300

301

302

303

304

305

306

307

308

309

310

311

arthropods in cattle dung pats. The arthropods found in caged dung pats can be were those

existing in the surrounding soil and those species that were small enough to fit through the

exclusion screen (e.g., flies laid their eggs on the screen, and neonate larvae fell through onto the dung pat). There was significantly higher arthropod abundance and biomass found in the

uncaged pats that were younger than $7 \mathrm{~d}$ old (Figures $1 \& 2$ ). These significantly higher numbers of early colonization corroborate previous work that showed that the highest densities of invertebrates occur between 2 and 5 d post-deposition (Kessler \& Balsbaugh 1972; Lee \& Wall 2006). Most of the arthropods found in the caged dung pats were small hydrophilid beetles, ptiliid beetles, mites, and Collembola, which collectively are described as "micro-coprophages". This group frequently colonized both caged and uncaged pats due to their small size and presence in the soil prior to cage placement. Another group found in both treatments was dipteran larvae; indeed, we found more maggots in the caged pats than the uncaged pats. Overall, there was a significant and substantial reduction in the biomass, abundance and diversity of most the dung arthropods in the cages.

Arthropod community complexity and abundance diminished as the pat aged past 7 days. Many of the early dung colonizers (flies and coprophagous beetles) consume small particles found in the liquid portion of freshly excreted pats (Holter \& Scholtz 2007). The offspring of these early dung pat colonizers add complexity to the community. Once sufficient numbers of these coprophages and their larvae have aggregated in the dung pat, a wave of predatory arthropods respond to this prey source (Koskela \& Hanski 1977). As the moisture evaporates from the dung, it becomes less attractive to many of the coprophages (Stevenson \& Dindal 1987). Additionally, many coprophages migrate to more recently deposited pats (McDaniel et al. 
312 1971; Mohr 1943). Predators follow these prey species (Slade et al. 2016; Sowig et al. 1997).

313 This succession of colonization is supported by observations of arthropods during this study.

314 Arthropod abundance decreased as the pats lost moisture, and by the time dung was $14 \mathrm{~d}$ old, the

315 arthropod community metrics and moisture content reached a constant low for the rest of the

316 observation period. These observations resemble the succession of dung colonization seen in

317 similar studies (Kessler \& Balsbaugh 1972; Mohr 1943; Valiela 1969).

318 In addition to their changes over the age of the pat, dung arthropod communities also

319 change over the season. Due to the resource intensity of this study, it was conducted on a single

320 ranch in a single year which challenges generalizations on seasonal patterns in dung

321 degradations. Nevertheless, some trends between the two observation dates are noteworthy. In

322 the early season, peak arthropod abundance was in $7 \mathrm{~d}$ old dung pats. Later in the season, peak

323 abundance was in 2 to $4 \mathrm{~d}$ old pats, with a more gradual decrease in abundance as the pat aged

324 (Figure 2). Several explanations may factor into these patterns of dung colonization.

325 Temperature has an important effect on dung colonization (Errouissi et al. 2004), with colder

326 temperatures affecting colonization and degradation rates. In this study, early season had a colder

327 temperature $\left(16.7^{\circ} \mathrm{C}\right.$ daily average $)$ than late season $\left(21.1^{\circ} \mathrm{C}\right.$ daily average $)$, and this may

328 partially explain our experimental results. Additionally, many arthropods, such as dung beetles,

329 do not share the same phenology, with many adults emerging and becoming active in different

330 times over the grazing season (Pecenka and Lundgren 2018 in review). Higher temperatures later

331 in the season would also dry the pat more quickly, and water content of the pat influences its

332 attraction to dung arthropods (Finn \& Giller 2000). This higher temperature causes the dung pat

333 to dry at a quicker rate, making it less attractive and suitable for dung beetles and other large

334 coprophagous arthropods. As the grazing season progresses, cool season grasses are replaced 
335 with warm season species (Ellis-Felege et al. 2013). The changes in palatability and digestibility

336 of different plants to cattle can affect the composition of the dung and its attractiveness to

337 arthropods (Holter 2016). Without further research, we cannot definitively say what drove these

338 slightly different patterns of colonization over the season, but these considerations become

339 important to ranchers wanting consistent dung degradation on their land.

340 These results provide further evidence that dung beetles contribute multiple ecosystem

341 functions to rangelands by the dung arthropod community (Beynon et al. 2012; Manning et al.

342 2016; Nichols et al. 2008). Arthropod communities are major contributors to dung degradation,

343 and dung beetle abundance and diversity influence many of the characteristics of this community

344 (abundance, richness, and diversity) (Table 2, Figure 4). Dung beetles were strongly correlated

345 with the overall arthropod community even though they represented only $1.5-3 \%$ of the

346 specimens collected in the study. Dung beetles colonize fresh dung pats and feed on the liquid

347 portion of the dung; they leave when water becomes limited (Holter \& Scholtz 2007). Dung

348 beetles may also deposit eggs in or underneath the dung pat, where their larvae will develop and

349 consume the dried fibrous portion of the dung pat that remains (Laurence 1954). Dung beetles

350 can also alter the dung pat and the arthropods that will colonize it. Through their tunneling and

351 bioturbation of the dung pat, they allow air to reach the center of the pat and cause it to degrade

352 faster by converting it into forms accessible to plant roots and microbes (Bang et al. 2005;

353 Bornemissza 1970; Stevenson \& Dindal 1987). We hypothesize that dung beetles' robust bodies

354 also provide a "highway system" that other arthropods such as predatory beetles or spiders can

355 use to search for prey such as pest maggots. These tunnels would then also open up the pat's

356 interior to the micro-coprophage community that lack the ability to burrow through the pat; 
357 further increasing their effect on pat degradation. Their impact can be seen in the large amount of

358 OM lost in the first days of arthropod colonization.

359

360 Conclusions.

361 - Degradation of dung pats was increased by $30 \%$ (approximately $30 \mathrm{~d}$ ) when the entire

362 insect community was present in the pats.

363 - Early colonization was essential to dung degradation. Most dung degradation occurred

364 within a week of dung deposition, and the main effects of insects on pat degradation

365 occurred within $2 \mathrm{~d}$ of pat deposition.

- Although dung beetles were only $1.5-3.0 \%$ of the arthropod community in dung, their abundance was strongly correlated with the rest of the community. This data supports their role as essential contributors to dung degradation.

369

370

\section{Acknowledgements}

371 Authors thank Mike Bredeson, Claire LaCanne, Amy Lieferman, Alexander Nikolas, Cassandra

372 Pecenka, and Kassidy Weathers for their assistance in construction, deploying, and field removal

373 of dung pat cages. Special thanks as well to Mark Longfellow in assisting with insect

374 identification, and K Creek Ranch for use of their pasture.

375

376

\section{References}

Aarons SR, O'Connor CR, Hosseini HM, and Gourley CJP. 2009. Dung pads increase pasture production, soil nutrients, and microbial biomass carbon in grazed dairy systems. Nutr Cycl Agroecosyst 84:81-92. relationship to increased dung fouling of rangeland pastures. J Econ Entomol 77:133141. 
383

384

385

386

387

388

389

390

391

392

393

394

395

396

397

398

399

400

401

402

403

404

405

406

407

408

409

410

411

412

413

414

415

416

417

418

419

420

421

422

423

424

425

Bang H, Lee J, Kwon O, Na Y, Jang Y, and Kim W. 2005. Effects of paracoprid dung beetles (Coleoptera: Scarabaeidae) on the growth of pasture herbage and on the underlying soil. App/ Soil Ecol 29: 165-171.

Beynon SA, Mann DJ, Slade EM, and Lewis OT. 2012. Species-rich dung beetle communities buffer ecosystem services in perturbed agro-ecosystems. J Appl Ecol 49:1365-1372.

Beynon SA, Wainwright WA, and Christie M. 2015. The application of an ecosystem services framework to estimate the economic value of dung beetles to the U. K. cattle industry. Ecol Entomol 40 (Suppl 1): 124-135

Blume RR. 1985. A check-list, distributional record, and annotated bibliography of the insects associated with bovine droppings on pasture in America north of Mexico. Southwest Entomol 9:1-55.

Bornemissza GF. 1970. An effect of dung beetle activity on plant yeild. Pedobiologia 10:1-7.

Cervenka VJ, and Moon RD. 1991. Arthropods associated with fresh cattle dung pats in Minnesota. J Kansas Entom Soc 64:131-145.

Cook DF, Dadour IR, and Ali DN. 1996. Effect of diet on the excretion profile of ivermectin in cattle faeces. Int J Parasitol 26:291-295.

Doube BM. 1990. A functional classification for analysis of the structure of dung beetle assemblages. Ecol Entomol 15:371-383.

Ellis-Felege SN, Dixon CS, and Wilson SD. 2013. Impacts and management of invasive coolseason grasses in the Northern Great Plains: challenges and opportunities for wildlife. Wildlife Soc B 37:510-516.

Errouissi FF, Haloti S, Jay-Robert P, Janati-Idrissi A, and Lumaret JP. 2004. Effects of the attractiveness for dung beetles of dung pat origin and size along a climatic gradient. Environ Entomol 33:45-53.

Fincher GT. 1981. The potential value of dung beetles in pasture ecosystems. J Georgia Entomol Soc 16.

Finn JA, and Giller PS. 2000. Patch size and colonisation patterns: an experimental analysis using north temperate coprophagous dung beetles. Ecography 23:315-327.

Gillard P. 1967. Coprophagous beetles in pasture ecosystems. J Aust I Agr Sci 33:30-34.

Haynes RJ, and Williams PH. 1993. Nutrient cycling and soil fertility in the grazed pasture ecosystem. Adv Agron 49:119-199.

Holter P. 1979. Effect of dung-beetles (Aphodius spp.) and earthworms on the disappearance of cattle dung. Oikos 32:393-402.

Holter P. 2016. Herbivore dung as food for dung beetles: elementary coprology for entomologists. Ecol Entomol 41:367-377. 10.1111/een.12316

Holter P, and Scholtz CH. 2007. What do dung beetles eat? Ecol Entomol 32:690-697.

Johnston CA. 2014. Agricultural expansion: land use shell game in the U.S. Northern Plains. Landscape Ecol 29:81-95.

Kaneda S, Yamashita N, Uchida T, Shimano S, Miyoshi N, Sasaki M, and Enami Y. 2005. Effects of ivermectin in dung pats on earthworm (Megascolecidae) populations and pat degradation in Japanses grassland. Applied Soil Ecology 31:280-285.

Kessler H, and Balsbaugh EU. 1972. Succession of Adult Coleoptera in Bovine Manure in East Central South Dakota. Ann Entomol Soc Am 65:1333-1336. 
426

427

428

429

430

431

432

433

434

435

436

437

438

439

440

441

442

443

444

445

446

447

448

449

450

451

452

453

454

455

456

457

458

459

460

461

462

463

464

465

466

467

468

469

Koskela H, and Hanski I. 1977. Structure and succession in a beetle community inhabiting cow dung. Ann Zool Fennici 14:204-223.

Laurence BR. 1954. The Larval Inhabitants of Cow Pats. J Anim Ecol 23:234-260.

Lee CM, and Wall R. 2006. Cow-dung colonization and decomposition following insect exclusion. Bull Entomol Res 96:315-322.

Losey JE, and Vaughan M. 2006. Economic Value of Ecological Services Provided by Insects. Bioscience 56:311-323.

MacLusky DS. 1960. Some estimates of the areas of pasture fouled by the excreta of dairy cows. J Br Grassld Soc 15:181-188.

Macqueen A, and Beirne P. 1975. Effects of cattle dung and dung beetle activity on growth of beardless wheatgrass in British Columbia. Can J Plant Sci 55:961-967.

Manning P, Slade EM, Beynon SA, and Lewis OT. 2016. Functionally rich dung beetle assemblages are required to provide multiple ecosystem services. Agr Ecosyst Environ 218:87-94.

McDaniel B, Boddicker ML, and Balsbaugh EU. 1971. Coleoptera Inhabiting Bovine Manure in a Pasture on the Big Sioux River Flood Plain in South Dakota. Proc SD Acad Sci 50:220-237.

Merritt RW, and Anderson JR. 1977. The effects of different pasture and rangeland ecosystems on the annual dynamics of insects in cattle droppings. Hilgardia 45:31-71.

Mohr CO. 1943. Cattle Droppings as Ecological Units. Ecol Monogr 13:275-298.

[NASS] National Agricultural Statisitics Service. 2016. United States Department of Agriculture. Web-based document. www.nass.usda.gov. Accessed December 20, 2016.

Nichols EE, Spector SS, Louzada JJ, Larsen TT, Amezquita SS, and Favila ME. 2008. Ecological functions and ecosystem services provided by Scarabaeinae dung beetles. Biol Conserv 141:1461-1474.

Penttila A, Slade EM, Simojoki A, Riutta T, Minkkinen K, and Roslin T. 2013. Quantifying BeetleMediated Effects on Gas Fluxes from Dung Pats. PLOS ONE 8:e71454.

Petersen RG, Lucas HL, and Woodhouse WW. 1956. The distribution of excreta by freely grazing cattle and its influence on pasture fertility: I. Excretal density. Agron J 48:440-444.

Ratcliffe, B. C., and M. J. Paulsen. 2008. The Scarabaeoid beetles of Nebraska (Coleoptera: Scarabaeoidea).

Bull. Univ. Nebr. State Mus. 22: 1-570.

Sanders DP, and Dobson RC. 1966. The Insect Complex Associated with Bovine Manure in Indiana. Ann Entomol Soc Am 59:955-959.

Slade EM, Roslin T, Santalahti M, and Bell T. 2016. Disentangling the 'brown world' faecaldetritus interaction web: dung beetle effects on soil microbial properties. Oikos 125:629-635.

Sowig P, Himmelsbach R, and Himmelsbach W. 1997. Predator - prey relationship between insect larvae: growth of Sphaeridium larvae (Coleoptera: Hydrophilidae) under time constraints through predation on Musca autumnalis maggots (Diptera: Muscidae). Can J Zool 75:2069-2076.

Stevenson BG, and Dindal DL. 1987. Insect effects on decomposition of cow dung in microcosms. Pedobiologia 30:81-92.

Strong L. 1992. Avermectins: a review of their impact on insects of cattle dung. Bull Entomol Res 82:265-274. 
470 Suarez VH, Lifschitz AL, Sallovitz JM, and Lanusse CE. 2003. Effects of ivermectin and

471

472

473

474

475

476

477

478

479

480

481

482

483

484

485

486

487

488

489

490

491

492

493

494 Entomol 127:481.

Tixier T, Lumaret JP, and Sullivan GT. 2015. Contribution of the timing of the successive waves of insect colonisation to dung removal in a grazed agro-ecosystem. Eur J Soil Biol 69:8893.

Triplehorn, C. A., and N. F. Johnson. "Borror and DeLong's Introduction to the Study of Insects. 2005." Thomson Brooks/Cole, Seventh Edition. USA (2005).

[USDA-NRCS] United States Department of Agriculture-Natural Resources Conservation Service. 2016. Web Soil Survey. Web-based document. www.websoilsurvey.nrcs.usda.gov. Accessed December 28, 2016.

Valiela I. 1969. The arthropod fauna of bovine dung in central New York and sources on its natural history. J of the New York Ent Soc 77:210-220.

Weeda WC. 1967. The effect of cattle dung patches on pasture growth, botanical composition, and pasture utilisation. New Zeal J Agr Res 10:150-159.

Wright CK, and Wimberly MC. 2012. Recent land use change in the Western Corn Belt threatens grasslands and wetlands. P Natl Acad Sci 110:4134-4139.

Wu X, and Sun S. 2010. The roles of beetles and flies in yak dung removal in an alpine meadow of eastern Qinghai-Tibetan Plateau. Ecoscience 17:146-155.

Yamada D, Imura O, Shi K, and Shibuya T. 2007. Effect of tunneler dung beetles on cattle dung decomposition, soil nutrients and herbage growth. Grass/ Sci 53:121-129. 


\section{Table Legends}

496 Table 1. The effects of age in days since deposition (0-42 days)on of the weight and ash-free

497 oganic matter of dung pats. These characteristics were studied over time when insects were

498 allowed access to (inclusion) or were excluded from the pats using cages. Communities were

499 sampled early in the season and late in the season, and are presented distinctly. Data presented

500 represents the mean \pm SEM. Capital letters represent differences over time and lower case letters

501 represent differences between treatments $(\alpha=0.05)$.

502 Table 2. Relationships of dung beetle abundance, richness, and diversity to the arthropod

503 community characteristics when complete insect communities were allowed access to dung

504 pats. Communities were sampled early in the season and late in the season, and are presented

505 distinctly. Data presented represents the mean \pm SEM. Statistical presentation are the result of

506 linear regressions, and $\alpha=0.05$

507

508 


\section{Figure Legends}

510 Figure 1. Arthropod dry weight biomass (mean \pm SEM) per cattle dung pat $(n=6)$ over the

511 age of the pat. Arthropods were excluded from half of the pats $(n=6$ pats per treatment per age $)$

512 using cages. Pats were examined beginning in June (A) and in late July (B). Asterisks above the

513 bars indicate significantly different arthropod biomasses in the caged and uncaged pats for that

514 specific sample age $(\alpha=0.05)$.

515 Figure 2. Arthropod abundance (mean \pm SEM) per cattle dung pat $(n=6)$ over the age of

516 the pat. Arthropods were excluded from half of the pats $(n=6$ pats per treatment per age) using

517 cages. Pats were examined beginning in June (A) and in late July (B). Asterisks above the bars

518 indicate significantly different arthropod abundances in the caged and uncaged pats for that

519 specific sample age $(\alpha=0.05)$.

520 Figure 3. Degradation rate of organic matter content (mean $\pm \mathrm{SEM}$ ) in cattle dung pats.

521 Dung pats were dried to $0 \%$ moisture and burned in furnace to remove all organic matter

522 allowing calculation of ash-free organic matter content (AFOM). AFOM content was calculated

523 in dung pats beginning in June (A) and late July (B). Arthropods were excluded from half of the

524 pats and were allowed access to the other half $(n=6$ pats per treatment per dung age).

525 Figure 4. Correlation of the diversity of dung beetles to total arthropod abundance in cattle

526 dung pats. A regression was used to examine correlations between dung beetle diversity

527 (Shannon $\mathrm{H}$ ) in dung pats and total arthropod abundance per individual cattle dung pat.

528 Beginning in June (A) and late July (B) there was a significant and positive correlation between

529 dung beetle diversity and the total arthropod abundance in dung pats ( $\mathrm{n}=36$ in both A and B). 


\section{Table $\mathbf{1}$ (on next page)}

The effects of age on degradation of physical and chemical characteristics of dung pats with arthropod community exclusion/inclusion.

Capital letters represent differences over time and lower case letters represent differences between treatments $(\alpha=0.05)$. 
1

2

3

4

5

6

7

8

9

10

11

12

13

14

15

16

Table 1.

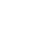

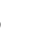

\begin{tabular}{lll}
\hline \hline Days & Wet weight of pat $(\mathrm{g})$ & Dry weight of pat $(\mathrm{g})$
\end{tabular}

4

6

\begin{tabular}{l}
\hline Early \\
Season
\end{tabular}

Exclusion cage

\section{Uncaged}

$772.78 \pm 24.34 \mathrm{Aa}$

$585.11 \pm 30.12 \mathrm{Ab}$

$697.25 \pm 15.58 \mathrm{Ba}$

$521.28 \pm 29.21 \mathrm{ABb}$

$648.55 \pm 24.70 \mathrm{Ba}$

$497.95 \pm 18.77 \mathrm{Bb}$

$359.96 \pm 17.28 \mathrm{Ca}$

$261.94 \pm 28.36 \mathrm{Cb}$

$28 \quad 290.15 \pm 18.59 \mathrm{Da}$

$215.04 \pm 9.89 \mathrm{Cb}$

$42 \quad 193.22 \pm 15.92 \mathrm{Ea}$

$133.88 \pm 5.40 \mathrm{Db}$

Exclusion cage
$193.05 \pm 4.18 \mathrm{Aa}$
$144.91 \pm 5.97 \mathrm{Ba}$
$135.5 \pm 2.76 \mathrm{BCa}$
$156.93 \pm 3.50 \mathrm{Ba}$
$135.75 \pm 3.24 \mathrm{BCa}$
$115.41 \pm 2.04 \mathrm{Da}$

Uncaged

$147.38 \pm 12.10 \mathrm{Ab}$

$103.14 \pm 7.14 \mathrm{BCb}$

$118.30 \pm 6.68 \mathrm{BCb}$

$103.87 \pm 10.77 \mathrm{BCb}$

$99.55 \pm 7.96 \mathrm{BDa}$

exclusion $\mathrm{F}_{1,60}=94.07, P<0.001$

exclusion: $\mathrm{F}_{1,60}=104.21, P<0.001$

time: $\mathrm{F}_{5,60}=207.96, P<0.001$

interaction: $\mathrm{F}_{5,60}=3.31, P=0.010$

$\begin{array}{ll}\text { Late } & 2 \\ \text { Season } & 4 \\ & 7\end{array}$

$829.21 \pm 14.04 \mathrm{Aa}$

$708.13 \pm 13.42 \mathrm{Ab}$

time: $\mathrm{F}_{5,60}=194.32, P<0.001$

interaction: $\mathrm{F}_{5}, 60=8.86, P<0.001$

$301.64 \pm 5.62 \mathrm{Aa} \quad 237.64 \pm 2.86 \mathrm{Ab}$

$217.66 \pm 6.64 \mathrm{Ba} \quad 186.75 \pm 1.55 \mathrm{Bb}$

$702.10 \pm 9.57 \mathrm{Ba} \quad 535.84 \pm 10.21 \mathrm{Bb}$

$220.30 \pm 2.23 \mathrm{Ba}$

$187.11 \pm 2.11 \mathrm{Bb}$

$741.68 \pm 10.95 \mathrm{Ba} \quad 630.58 \pm 7.10 \mathrm{Cb}$

$227.27 \pm 6.99 \mathrm{Ba} \quad 169.89 \pm 3.89 \mathrm{Cb}$

$14 \quad 712.34 \pm 13.14 \mathrm{Ba} \quad 605.70 \pm 9.85 \mathrm{Cb}$

$191.33 \pm 2.80 \mathrm{Ca}$

$115.69 \pm 4.09 \mathrm{Db}$

$181.30 \pm 3.79 \mathrm{Ca}$

$117.21 \pm 4.52 \mathrm{Db}$

exclusion: $\mathrm{F}_{1,60}=482.79, P<0.001$

time: $\mathrm{F}_{5,60}=208.54, P<0.001$

interaction: $\mathrm{F}_{5,60}=9.02, P<0.001$

time: $\mathrm{F}_{5,60}=703.00, P<0.001$

interaction: $\mathrm{F}_{5,60}=5.68, P<0.001$

\begin{tabular}{|c|c|c|c|c|c|}
\hline & \multirow[t]{2}{*}{ Days } & \multicolumn{2}{|c|}{$\begin{array}{l}\text { Ash free organic matter } \\
\text { weight of dried dung (g) }\end{array}$} & \multicolumn{2}{|c|}{$\begin{array}{c}\text { Ash free organic matter } \\
\text { (\% of dry weight) }\end{array}$} \\
\hline \multirow{7}{*}{$\begin{array}{l}\text { Early } \\
\text { Season }\end{array}$} & & Exclusion cage & Uncaged & Exclusion cage & Uncaged \\
\hline & 2 & $168.09 \pm 3.63 \mathrm{Aa}$ & $116.57 \pm 9.19 \mathrm{Ab}$ & $87.12 \pm 1.21 \mathrm{Aa}$ & $79.20 \pm 0.48 \mathrm{Ab}$ \\
\hline & 4 & $125.12 \pm 6.06 \mathrm{Ba}$ & $80.83 \pm 5.27 \mathrm{Bb}$ & $86.27 \pm 1.49 \mathrm{ABa}$ & $78.52 \pm 1.12 \mathrm{Ab}$ \\
\hline & 7 & $114.67 \pm 1.90 \mathrm{BCa}$ & $92.32 \pm 5.41 \mathrm{Bb}$ & $84.65 \pm 0.60 \mathrm{ABa}$ & $78.01 \pm 0.53 \mathrm{ABb}$ \\
\hline & 14 & $133.28 \pm 3.11 \mathrm{Ba}$ & $79.51 \pm 8.08 \mathrm{BCb}$ & $84.93 \pm 0.69 \mathrm{ABa}$ & $76.60 \pm 0.65 \mathrm{Bb}$ \\
\hline & 28 & $114.51 \pm 3.07 \mathrm{BCa}$ & $74.13 \pm 5.63 \mathrm{BCb}$ & $84.33 \pm 0.27 \mathrm{Ba}$ & $74.61 \pm 0.50 \mathrm{Ca}$ \\
\hline & 42 & $92.57 \pm 1.72 \mathrm{Da}$ & $58.67 \pm 2.32 \mathrm{Db}$ & $80.21 \pm 0.53 \mathrm{Ca}$ & $69.70 \pm 0.23 \mathrm{Db}$ \\
\hline & & \multicolumn{2}{|c|}{$\begin{array}{c}\text { exclusion: } \mathrm{F}_{1,60}=182.80, P<0.001 \\
\text { time: } \mathrm{F}_{5,60}=34.55, P<0.001 \\
\text { interaction: } \mathrm{F}_{5,60}=2.45, P=0.044\end{array}$} & \multicolumn{2}{|c|}{$\begin{array}{c}\text { exclusion: } \mathrm{F}_{1,60}=350.22, P<0.001 \\
\text { time: } \mathrm{F}_{5,60}=28.11, P<0.001 \\
\text { interaction: } \mathrm{F}_{5,60}=1.60, P=0.175\end{array}$} \\
\hline \multirow{7}{*}{$\begin{array}{l}\text { Late } \\
\text { Season }\end{array}$} & 2 & $267.33 \pm 6.44 \mathrm{Aa}$ & $204.23 \pm 3.92 \mathrm{Ab}$ & $88.58 \pm 0.59 \mathrm{Aa}$ & $85.91 \pm 0.82 \mathrm{Ab}$ \\
\hline & 4 & $190.59 \pm 5.55 \mathrm{Ba}$ & $158.49 \pm 1.50 \mathrm{Bb}$ & $87.59 \pm 0.53 \mathrm{ABa}$ & $84.87 \pm 0.80 \mathrm{ABb}$ \\
\hline & 7 & $192.65 \pm 1.83 \mathrm{Ba}$ & $158.61 \pm 2.49 \mathrm{Bb}$ & $87.17 \pm 0.46 \mathrm{ABCa}$ & $84.75 \pm 0.96 \mathrm{ABa}$ \\
\hline & 14 & $197.65 \pm 6.51 \mathrm{Ba}$ & $141.99 \pm 2.91 \mathrm{Cb}$ & $86.95 \pm 0.60 \mathrm{BCa}$ & $83.61 \pm 0.85 \mathrm{Bb}$ \\
\hline & 28 & $164.24 \pm 2.55 \mathrm{Ca}$ & $94.55 \pm 3.17 \mathrm{Db}$ & $85.84 \pm 0.42 \mathrm{Ca}$ & $81.76 \pm 0.89 \mathrm{Cb}$ \\
\hline & 42 & $155.66 \pm 2.85 \mathrm{Ca}$ & $93.63 \pm 3.61 \mathrm{Db}$ & $85.88 \pm 0.38 \mathrm{Ca}$ & $79.88 \pm 0.47 \mathrm{Db}$ \\
\hline & & \multicolumn{2}{|c|}{$\begin{array}{c}\text { exclusion: } \mathrm{F}_{1,60}=531.25, P<0.001 \\
\text { time: } \mathrm{F}_{5,60}=205.94, P<0.001 \\
\text { interaction: } \mathrm{F}_{5,60}=8.23, P<0.001\end{array}$} & \multicolumn{2}{|c|}{$\begin{array}{c}\text { exclusion: } \mathrm{F}_{1,60}=144.60, P<0.001 \\
\text { time: } \mathrm{F}_{5,60}=20.26, P<0.001 \\
\text { interaction: } \mathrm{F}_{5,60}=3.49, P<0.001\end{array}$} \\
\hline
\end{tabular}


Table 2 (on next page)

Relationships of dung beetle abundance, richness, and diversity to the arthropod community characteristics in inclusion dung pats throughout grazing season.

Statistical presentations are the result of linear regressions, and $\alpha=0.05$. 
1 Table 2.

2

3

\begin{tabular}{|c|c|c|c|c|}
\hline & \multirow[b]{2}{*}{ Characteristic } & \multicolumn{3}{|c|}{ Dung beetle } \\
\hline & & Abundance & Richness & Diversity \\
\hline \multirow[t]{4}{*}{ Early season } & $\begin{array}{l}\text { Arthropod } \\
\text { biomass (mg) }\end{array}$ & $\begin{array}{c}\mathrm{F}_{1,35}=47.64 \\
P<0.001\end{array}$ & $\begin{array}{c}\mathrm{F}_{1,35}=74.46 \\
P<0.001\end{array}$ & $\begin{array}{c}\mathrm{F}_{1,35}=59.42 \\
P<0.001\end{array}$ \\
\hline & $\begin{array}{l}\text { Arthropod } \\
\text { abundance }\end{array}$ & $\begin{aligned} \mathrm{F}_{1,35} & =44.84 \\
P & <0.001\end{aligned}$ & $\begin{array}{c}\mathrm{F}_{1,35}=15.07 \\
P<0.001\end{array}$ & $\begin{array}{c}\mathrm{F}_{1,35}=10.73 \\
P=0.001\end{array}$ \\
\hline & Species richness & $\begin{array}{c}\mathrm{F}_{1,35}=42.53 \\
P<0.001\end{array}$ & $\begin{array}{c}\mathrm{F}_{1,35}=74.46 \\
P<0.001\end{array}$ & $\begin{array}{c}\mathrm{F}_{1,35}=16.31 \\
P<0.001\end{array}$ \\
\hline & $\begin{array}{l}\text { Micro-coprophage } \\
\text { abundance }\end{array}$ & $\begin{array}{c}\mathrm{F}_{1,35}=52.80 \\
P<0.001\end{array}$ & $\begin{array}{c}\mathrm{F}_{1,35}=19.69 \\
P<0.001\end{array}$ & $\begin{array}{c}\mathrm{F}_{1,35}=15.16 \\
P<0.001\end{array}$ \\
\hline \multirow[t]{4}{*}{ Late season } & $\begin{array}{l}\text { Arthropod } \\
\text { biomass (mg) }\end{array}$ & $\begin{array}{c}\mathrm{F}_{1,34}=70.80 \\
P<0.001\end{array}$ & $\begin{array}{c}\mathrm{F}_{1,34}=63.94, \\
P<0.001\end{array}$ & $\begin{array}{c}\mathrm{F}_{1,34}=61.20 \\
P<0.001\end{array}$ \\
\hline & $\begin{array}{l}\text { Arthropod } \\
\text { abundance }\end{array}$ & $\begin{array}{c}\mathrm{F}_{1,34}=27.23 \\
P<0.001\end{array}$ & $\begin{array}{c}\mathrm{F}_{1,34}=30.00 \\
P<0.001\end{array}$ & $\begin{array}{c}\mathrm{F}_{1,34}=27.54 \\
P<0.001\end{array}$ \\
\hline & Species richness & $\begin{array}{c}\mathrm{F}_{1,34}=42.95 \\
P<0.001\end{array}$ & $\begin{aligned} \mathrm{F}_{1,34} & =63.94 \\
P & <0.001\end{aligned}$ & $\begin{array}{c}\mathrm{F}_{1,34}=81.97 \\
P<0.001\end{array}$ \\
\hline & $\begin{array}{l}\text { Micro-coprophage } \\
\text { richness }\end{array}$ & $\begin{array}{c}\mathrm{F}_{1,34}=25.06 \\
P<0.001\end{array}$ & $\begin{array}{c}\mathrm{F}_{1,34}=28.65 \\
P<0.001\end{array}$ & $\begin{array}{c}\mathrm{F}_{1,34}=28.31, \\
P<0.001\end{array}$ \\
\hline
\end{tabular}




\section{Figure 1}

Arthropod dry weight biomass (mean \pm SEM) per cattle dung pat $(n=6)$ over the age of the pat.

Arthropods were excluded from half of the pats ( $n=6$ pats per treatment per age) using cages. Pats were examined beginning in June (A) and in late July (B). Asterisks above the bars indicate significantly different arthropod biomasses in the caged and uncaged pats for that specific sample age $(\alpha=0.05)$. 


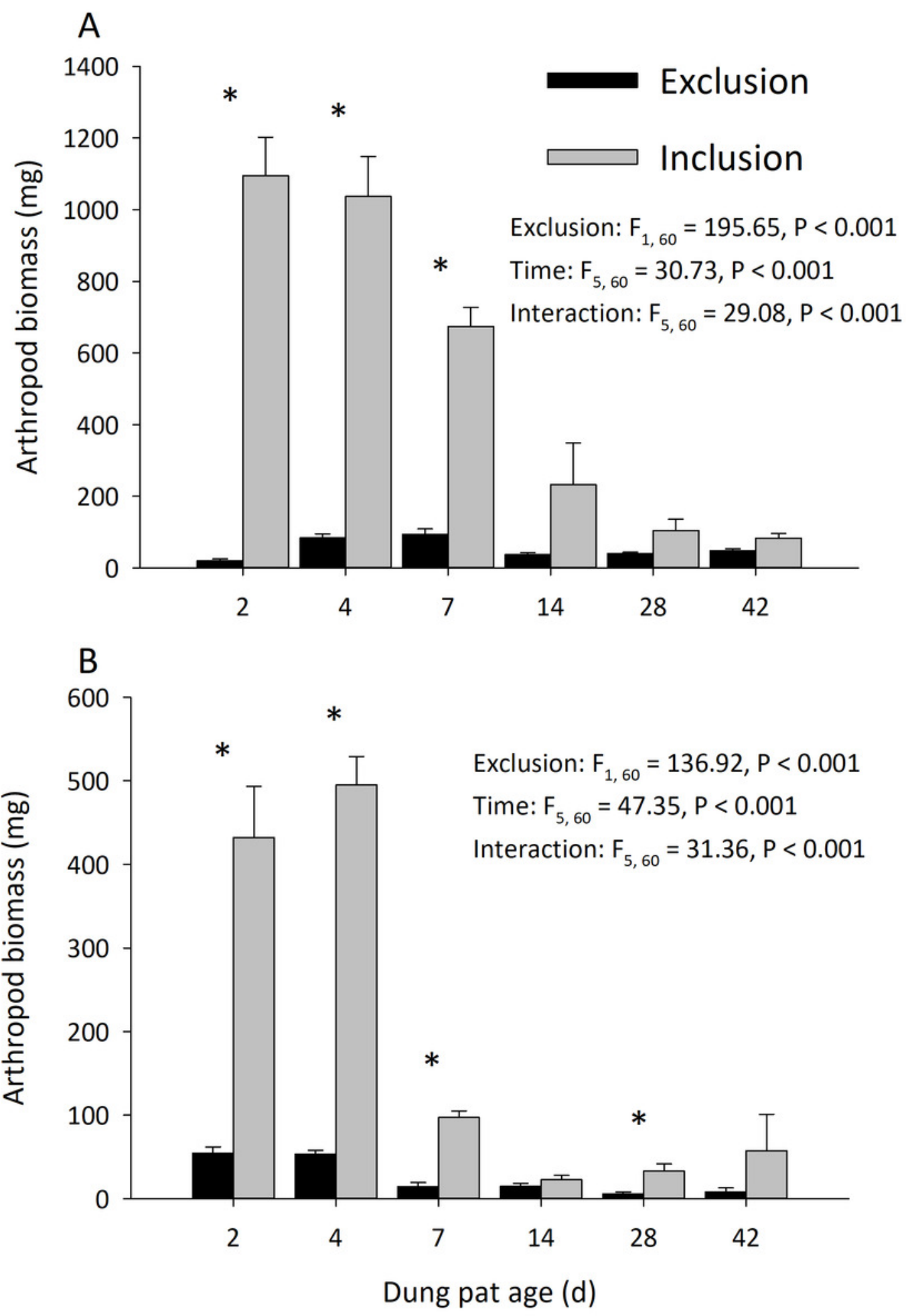




\section{Figure 2}

Arthropod abundance (mean \pm SEM) per cattle dung pat $(n=6)$ over the age of the pat.

Arthropods were excluded from half of the pats ( $n=6$ pats per treatment per age) using

cages. Pats were examined beginning in June (A) and in late July (B). Asterisks above the bars indicate significantly different arthropod abundances in the caged and uncaged pats for that specific sample age $(\alpha=0.05)$. 


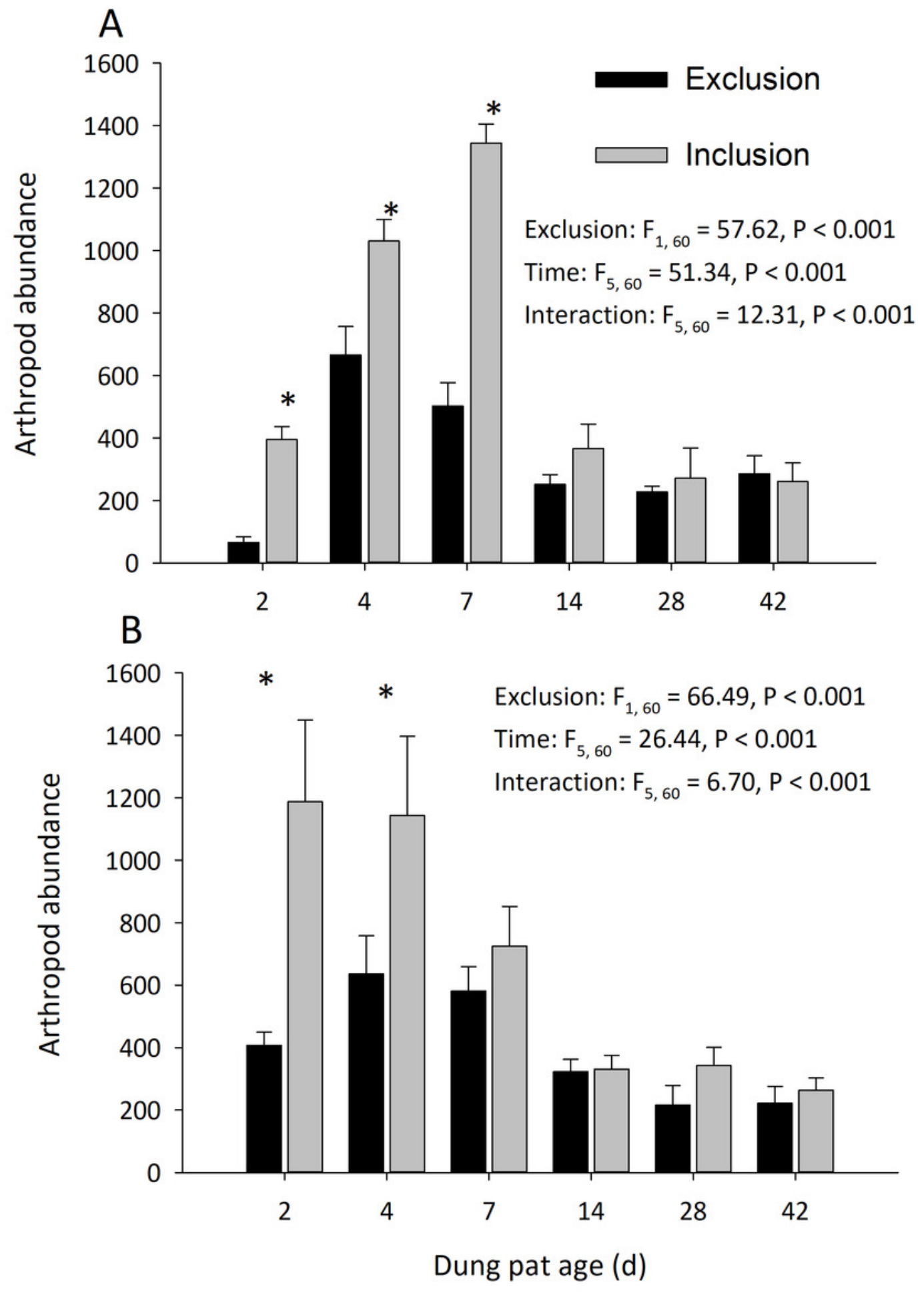




\section{Figure 3}

Degradation rate of organic matter content (mean \pm SEM) in cattle dung pats.

Dung pats were dried to $0 \%$ moisture and burned in furnace to remove all organic matter allowing calculation of ash-free organic matter content (AFOM). AFOM content was calculated in dung pats beginning in June (A) and late July (B). Half of pats had arthropods excluded ( $n=$ 6 pats per treatment per dung age) compared to allowing uninhibited arthropod colonization. 

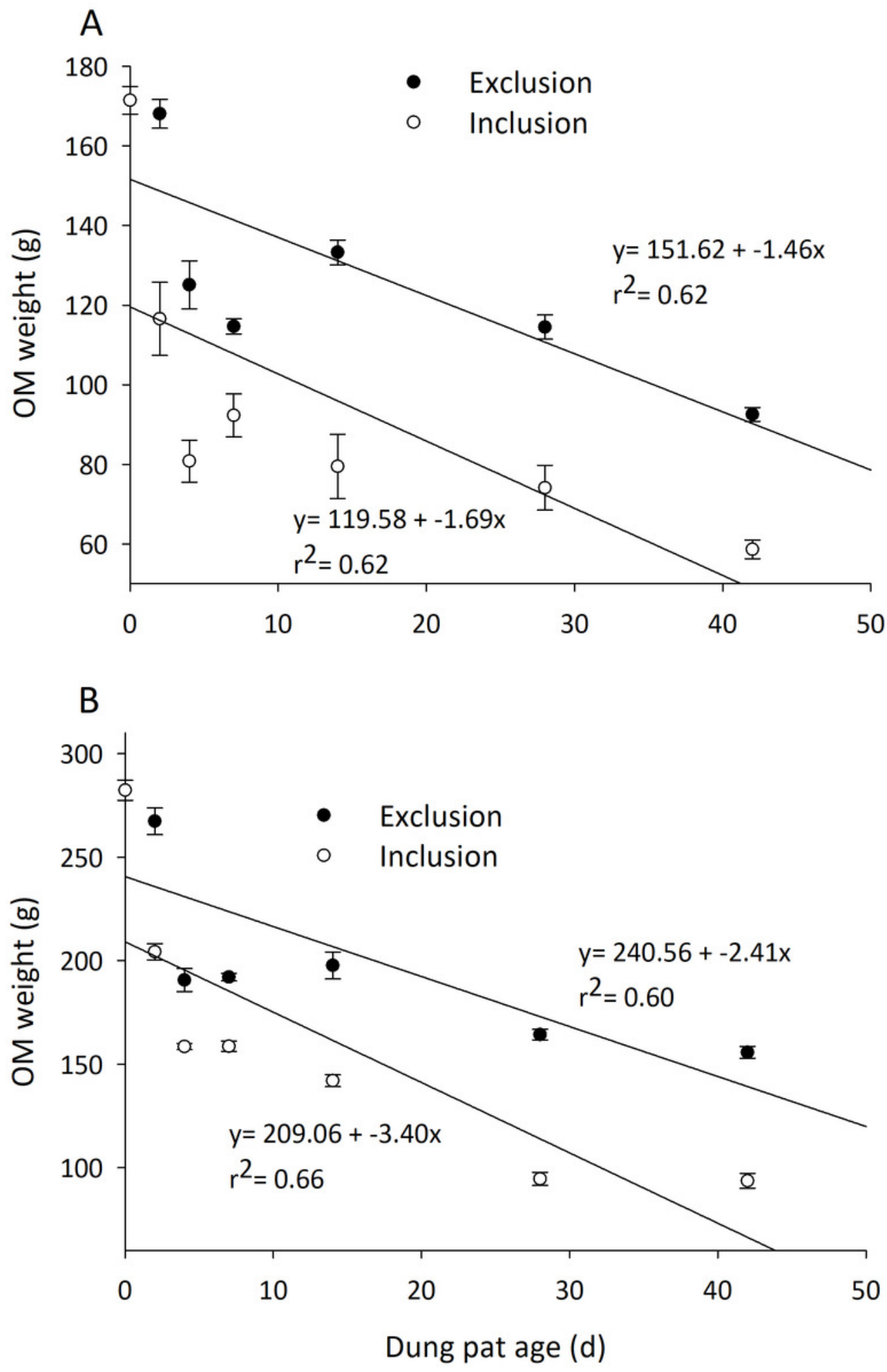


\section{Figure 4}

Correlation of the diversity of dung beetles to total arthropod abundance in cattle dung pats.

Dung beetle diversity (Shannon $\mathrm{H}$ ) in dung pats was run in a linear regression to observe correlation to total arthropod abundance per individual cattle dung pat. Beginning in June (A) and late July (B) there was a significant and positive correlation between dung beetle diversity and the total arthropod abundance in dung pats that all species could freely colonize ( $n=36$ in both $A$ and $B)$. 

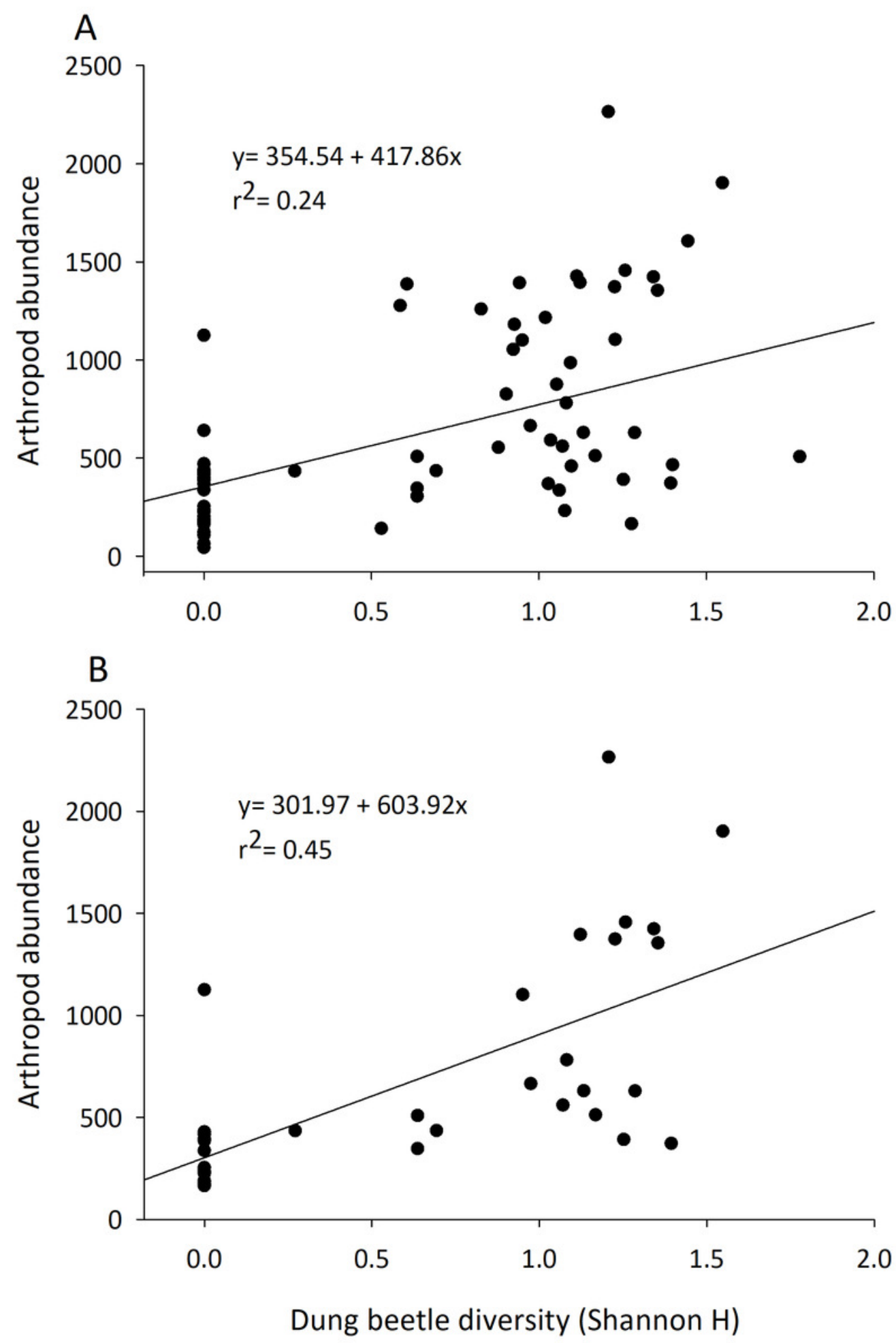